\title{
Conceptual Model for Effective Board Composition in the Context of Emerging Markets
}

\author{
Madi Almadi ${ }^{1}$ \\ ${ }^{1}$ RMIT University, Australia \\ Correspondence: Madi Almadi, Graduate School of Business and Law, RMIT University, Melbourne, VIC, 3000, \\ Australia. Tel: 61-03-9925-2000. E-mail: madi.almadi@ @mit.edu.au
}

Received: November 4, 2015

Accepted: November 21, $2015 \quad$ Online Published: December 25, 2015

doi:10.5539/ijef.v8n1p38

URL: http://dx.doi.org/10.5539/ijef.v8n1p38

\begin{abstract}
The impact of context has little or no consideration in the mainstream corporate governance literature. The purpose of this paper is to consider social, economic, and political elements of the emerging Saudi Arabian market when developing a multi-theoretical model about the relationship between board composition and financial performance. The paper attempts to conceptually inform the conversation about context with regard to board composition and firm financial performance in emerging markets. In particular, it discusses these theoretical feedback loops in conjunction with a proposed research agenda for the field. The paper proposes shifting the focus of corporate governance in emerging markets from relying on the predominant Western corporate governance theories to the alignment of those theories with considerations on emerging markets context. Such an approach involves significant implications for corporate governance theories and management practices. The paper describes the conditions in which certain formation of board of directors is composed in the Saudi Arabia may generate a competitive advantage. The consideration of emerging markets context can have implications for society as it may influence firms and governments to improve corporate governance standards and practices A literature gap in the corporate governance literature identified in this paper holds theoretical and practical implications. This research will enable comparative studies with other emerging markets, and will provide a conceptual benchmark for future corporate governance research.
\end{abstract}

Keywords: board composition, theory in context, firm financial performance, emerging markets, Saudi Arabia

\section{Introduction}

Board composition has a substantial influence on the practice of corporate governance in advanced markets, as well as in emerging markets such as Saudi Arabia (Allen et al., 2005; Marquis \& Raynard, 2015). Saudi Arabia is a vibrant economy and society with an emerging stock market known as Tadawul.

The Saudi Arabian (Saudi) economy, government, business and society has unique characteristics such as wealthy commercially active families, a strong oil industry, an influential public service, a budget for major infrastructure projects, the socially and commercially influential Najd region, and a royal family (The World Bank, 2009). These unique characteristics in the Saudi Arabian context have an influence on past, current and future corporate governance practices. There are no standard practices on board composition in emerging markets, as there are different social, cultural, and political elements in each particular country context (Wright et al., 2005; Xu \& Meyer, 2013). In comparison with advanced markets, emerging markets do not have well-established and mature business institutions, legal statutes, legal systems and infrastructure to help to manage corporate governance challenges (Claessens \& Yurtoglu, 2013).

In the Saudi context the business community and government viewed the issue of board composition for Tadawul listed companies as a secondary consideration up to the beginning of 2006 when Tadawul lost half of its value in a two month period (Al-Twaijry, 2007). Following this collapse in the value of Tadawul the Capital Market Authority (CMA) issued the first publication of corporate governance principles late in 2006 and these were later revised in 2009. The premise of these principles was to regulate the stock market and increase the credibility and transparency of Tadawul listed companies (CMA, 2012).

Against this background the purpose of this conceptual paper is to better understand corporate governance theory and practice in the unique business, economic and social context of the comparatively youthful, emerging Saudi 
stock market. Much of the corporate governance research conducted within the Saudi context so far has mainly focused on investigating corporate governance practices from a legal, accounting, and social perspective (Al-Matari et al., 2012). In this paper we advance knowledge of Saudi corporate governance by making two important contributions. First, drawing on agency, hegemony, institutional, resource dependence and stewardship theory a multi-theoretic perspective is given to explaining the relationship between key aspects of board composition and firm financial performance in the emerging Saudi stock market context (Boyd et al., 2011). A series of research propositions are developed. Second, reflecting on the insight gained from connecting a multi-theoretical corporate governance perspective to theory development in Saudi Arabia the discussion considers theoretical and practical implications beyond Saudi Arabia that may be relevant and insightful to policy makers and practitioners in other emerging stock markets. In this way we also contribute to theory of context.

The research questions that inform this paper are as follows: What are the most favourable choices for board of director composition with a view to financial performance in the emerging stock market of Saudi Arabia? What are the implications of insights on board composition and firm financial performance in Saudi Arabia for other emerging stock markets? The remainder of this manuscript is organised as follows. The second section reviews related literature in corporate governance and emerging markets. In the third section the paper develops research propositions and a conceptual model, followed fourth by the discussion and conclusion section including theoretical implications, practical implications, limitations, future research, and concluding remarks.

\section{Theoretical Background}

Corporate governance scholars have acknowledged little systematic evidence of board composition effect on firm financial performance. Withers et al. (2012), and Johnson et al. (2013) argue that those conclusions are probably the result of reliance on a single or two theoretical approaches. To gain broader insights into this phenomenon in the Saudi context, the theoretical background of this paper will draw on agency, hegemony, resource dependence, and stewardship theory (Note 1). This will be supplemented with other insights related to the emerging markets context including trends in business, economy and society.

Agency theory posits that directors are agent representing the shareholders, responsible for overseeing and the activities of management (Jensen \& Meckling, 1976; Johnson et al., 1996; Boyd et al., 2011). The theory primarily recognizes that independent directors as a key control instrument that prevent the principal-agent conflicts to occur (Karolyi, 2012). An additional view of agency theorists is that the main value of institutional investors (e.g. government departments, insurance companies) is to improve the board's monitoring mechanisms. Johnson et al. (1996) suggest that many private institutional investors, such as private banks and insurance companies can face potential conflicts of interest however public pension funds 'are virtually free of such conflicts' (p. 415). Board composed of active independents and institutional investors, especially public ones, would strengthen the control mechanisms of the board, thereby enhancing firm financial performance (Withers et al., 2012). However, Johnson et al. (2013) argue that the theory suffers from the lack of considerations to significant social and behavioural elements, importantly relevant to emerging markets. Thus development of research insight supported by other theoretical approaches is recommended.

In addition, Hegemony theory implies that individuals with prestigious status in society dominate the board of the directors (Burris, 2005). Such domination means the elimination or reduction of the influence of other social groups, and hence the interests of the elites are protected (Useem, 1984). The theory further advocates that directorial interlock is the main instrument for these directors to maintain and extend their power and status (Burris, 2005). Given their influence, the theory suggests that these directors can benefit the firm and have a mutual benefit with the rest of shareholders. Precisely, Huse et al. (2011) specify that outside directors with prestige or status can reduce market risks by horizontal integration (i.e. when some competitors are connected together through interlocking directorates), or vertical coordination (i.e. when suppliers or customers are invited to be board members). Moreover, due to their influential interlocks, outside directors with high status can provide access to vital resources with favourable financial consequences for the firm (Davis et al., 2003). However, hegemony theory is criticized for ignoring the changing structure of firm ownership. Zahra and Pearce (1989) argue that the fact that some individual investors still own a sizable share of company equity, private and public institutional investors have become the leading force in modern markets. Therefore, exclusive reliance on the theorized power of the elite in the board is not justified given the increasing influence of public and private institutional investors. Other governance theories would have the potential to yield further insights.

Furthermore, where outside directors have experience and linkages relevant to the firm's external environment, resource dependency theory suggests that these directors can assist the board in securing favourable access to 
resources for their employers (Pfeffer, 1972; Peng, 2004). Due to their expertise and influence with the public service, institutional representative directors can assist the company in preventing costly missteps when its activities may unintentionally conflict with the interests of these agencies (Bazerman \& Schoorman, 1983). Increasing coordination with the central authorities and other businesses gives access to critical information, increases the firm's legitimacy, and improves firm financial performance (Hillman et al., 2000). Although resource dependence theory and hegemony theory have similar views on how directorial interlocks can benefit the firm, the resource dependence theory emphasizes that the board member is being selected by the corporation rather than a social class (Zahra \& Pearce, 1989). Outside directors can also offer advice and counsel regarding general management and strategic choices (Pfeffer \& Salancik, 1978). Outside directors with strong human capital affect how board members consider and evaluate management decisions. While resource dependence theory has become accepted and used in many studies, the resource role of the board has not been as thoroughly examined as it could be (Johnson et al., 2013). Accompanying resource dependence theory with other relevant theoretical approaches would enable a better understanding of the value of this theory.

It has to be noted that agency, hegemony and resource dependence are organizational theories built upon economic rationality (Perrow, 1986). On the other hand, stewardship theory largely ignores that and rather emphasises the behavioural aspects of the agent (Donaldson \& Davis, 1991). Stewardship theory proposes that executives and managers are good stewards whose motivations are aligned with the interests of shareholders (Davis et al., 1997). These executives and managers are assumed to be trustworthy, committed, well informed, are good monitors and will not misuse firm resources; stewardship theory advocates that one or more company executives should be appointed to the board (Coles et al., 2001; Nicholson \& Kiel, 2007). Stewardship theory opposes the agency theory view in relation to the value of a majority of independent directors; stewardship theory views the presence of independent directors as neither critical nor essential (Dalton et al., 1998).

Moreover, most of the relevant literature on corporate governance has been based on advanced market studies. Mueller (2006) and Fan et al. (2011) suggest that agency, hegemony, resource dependence, and stewardship theories have been developed in the context of advanced economies, leaving little or no consideration of the unique social, political, and economic contexts presented in emerging stock markets such as Saudi Arabia. More importantly, previous research has largely neglected bundling contextual considerations of emerging markets with theory, and rather have deployed in parallel with it (Xu \& Meyer, 2013). The lack of integration between theory and context means an accurate diagnosis of a phenomenon in emerging markets would not be achieved. According to Huse et al. (2011, p. 12), understanding the relationship between board composition and firm financial performance in emerging markets 'requires an explicit involvement of context that underline the premise of the research'. Such alignment remains relatively scarce (Kearney, 2012), and in some contexts like the emerging Saudi Arabian market is absent.

In this regard, institutional theory has become the leading theory to be aligned with when studying corporate governance issues in the context of emerging countries (Hoskisson et al., 2000). Institutions such as political, economic, social, and educational bodies affect the stock market and company practice, and influence the strategic direction of these organizations. In emerging economies, firms are often led by informal institutions such as influential families and business groups (Peng, 2004). These business arrangements can result inefficient governance standards, thereby creating weak governance environments (Wright et al., 2005). Laws that that regulate fundamental elements of corporate governance such as transparency of management to shareholders, accounting standards, and board composition are either absent or ineffective (Millar et al., 2005). Hence, firms in emerging countries tend to rely on reputation and trust as a substitute for absence of effective regulations (Allen, 2005; Xu \& Meyer, 2013).

Another consideration is that as the institutional context in emerging markets makes the enforcement of business contracts more challenging and expensive, concentrated ownership occurs as a response. Yet, this strategy can fuel the development of principal-principal conflicts (Young et al., 2008). The principal-principal problems occur when the controlling shareholders oppress minority shareholders through their presence on the board of directors (Phan, 2001). Principal-principal conflicts can negatively impact firm strategy choices, dividend policy, stock prices, and lead to the high chance of expropriation of minority shareholders (Young et al., 2008). Moreover, Peng (2004) suggests that listed companies in emerging countries are likely to be under pressure to maintain legitimacy and transparency as a response to political and public demands. As a response, he clarifies that these firms would appoint independent directors for only symbolic purposes. While these firms strategically comply with these demands, they usually subtly limit the independence of those directors (Khanna \& Thomas, 2009). For instance directors may formally appear to be independent, but their independence can be reduced for example by social links with other board members (Claessens \& Yurtoglu, 2013). 
As institutions, management and learning processes in emerging countries are improving, Hoskisson et al. (2000) and $\mathrm{Xu}$ and Meyer (2013) recommend furthering corporate governance theories that were tested in advanced economies by explicitly aligning them with the distinctive social, political, and economic contexts of emerging markets. Such an approach would make a significant contribution to corporate governance literature, and could improve corporate governance practices in emerging markets (Whetten, 2009; Kearney, 2012; Mallin, 2013). Table 1 below provides a summary of representative studies that underpin the theoretical background presented here.

Table 1. Summary of the main considerations of emerging markets context when investigating the relationship between board composition and firm financial performance

\begin{tabular}{|c|c|c|c|c|}
\hline Authors & $\begin{array}{l}\text { Primary } \\
\text { Approaches }\end{array}$ & Data and Context & $\begin{array}{l}\text { Analytical } \\
\text { Techniques }\end{array}$ & Main Findings \\
\hline $\begin{array}{l}\text { Phan } \\
(2001)\end{array}$ & Agency theory & Theoretical paper & NA & $\begin{array}{l}\text { Owners in emerging markets tend to retain control } \\
\text { while transferring the risk of ownership through their } \\
\text { social or business associates. This has led to serious } \\
\text { problems associated with the reduction of minority } \\
\text { shareholder rights by the controlling shareholder. }\end{array}$ \\
\hline $\begin{array}{l}\text { Klapper } \\
\text { and Love } \\
\text { (2004) }\end{array}$ & Institutional theory & $\begin{array}{l}\text { Secondary data set of } 495 \\
\text { companies in } 25 \text { countries } \\
\text { between } 1995 \text { and } 1999\end{array}$ & $\begin{array}{l}\text { Multiple } \\
\text { Regression }\end{array}$ & $\begin{array}{l}\text { Firms can compensate for ineffective laws by } \\
\text { establishing good corporate governance. }\end{array}$ \\
\hline $\begin{array}{l}\text { Peng } \\
(2004)\end{array}$ & $\begin{array}{lr}\text { Agency, } & \text { Resource } \\
\text { Dependence } & \text { and } \\
\text { Institutional theories }\end{array}$ & $\begin{array}{l}\text { Secondary data set of } 530 \\
\text { between } 1992 \text { and } 1996\end{array}$ & $\begin{array}{l}\text { Multiple } \\
\text { Regression }\end{array}$ & $\begin{array}{l}\text { Due to their human and social capital, outside } \\
\text { directors have a positive effect on firm growth in } \\
\text { emerging markets. }\end{array}$ \\
\hline $\begin{array}{l}\text { Allen } \\
(2005)\end{array}$ & $\begin{array}{l}\text { Cooperative Theory and } \\
\text { Institutional theories }\end{array}$ & Theoretical paper & NA & $\begin{array}{l}\text { In the absence of effective regulations, relying on } \\
\text { reputation and trust can improve corporate governance } \\
\text { in emerging markets; this will lead to better } \\
\text { performance. }\end{array}$ \\
\hline $\begin{array}{l}\text { Wright et } \\
\text { al. (2005) }\end{array}$ & $\begin{array}{lr}\text { Agency, } & \text { Resource } \\
\text { Dependence, } & \text { Transaction } \\
\text { and Institutional theories }\end{array}$ & Theoretical paper & NA & $\begin{array}{l}\text { Business arrangements have evolved in emerging } \\
\text { countries as a way of dealing with problems of } \\
\text { underdeveloped market institutions. Yet, as emerging } \\
\text { economies develop, institutional theory would become } \\
\text { less relevant than other corporate governance } \\
\text { approaches. }\end{array}$ \\
\hline $\begin{array}{l}\text { Young et } \\
\text { al. (2008) }\end{array}$ & $\begin{array}{l}\text { Agency, } \quad \text { Resource } \\
\text { Dependence and } \\
\text { Institutional theories }\end{array}$ & Theoretical paper & NA & $\begin{array}{l}\text { As emerging markets become more open, the exposure } \\
\text { to outside ideas and influence will likely advance } \\
\text { governance reforms. }\end{array}$ \\
\hline $\begin{array}{l}\text { Fan, Wei } \\
\text { and } \mathrm{Xu} \\
(2011)\end{array}$ & $\begin{array}{l}\text { Institutional and market } \\
\text { behaviour theories }\end{array}$ & Theoretical paper & NA & $\begin{array}{l}\text { Firm external environment is more likely to } \\
\text { contribute to the behavioral differences towards the } \\
\text { adoption of corporate governance standards between } \\
\text { emerging and developed markets. }\end{array}$ \\
\hline $\begin{array}{l}\text { Millar et } \\
\text { al. (2005) }\end{array}$ & Institutional theory & Theoretical paper & NA & $\begin{array}{l}\text { Transparency is viewed to be one of the main factors } \\
\text { of the success of corporate governance } \\
\text { implementation in emerging markets. }\end{array}$ \\
\hline $\begin{array}{l}\text { Mueller } \\
(2006)\end{array}$ & $\begin{array}{l}\text { Agency and Institutional } \\
\text { theories }\end{array}$ & $\begin{array}{l}\text { Secondary data set of } 60 \\
\text { countries between } 1960 \text { and } \\
1998\end{array}$ & $\begin{array}{l}\text { Content } \\
\text { Analysis }\end{array}$ & $\begin{array}{l}\text { Investors would buy shares in emerging markets } \\
\text { firms even without having robust legal protection, } \\
\text { because they expect their investment will receive high } \\
\text { returns. }\end{array}$ \\
\hline $\begin{array}{l}\text { Khanna } \\
\text { and } \\
\text { Thomas } \\
\text { (2009) }\end{array}$ & $\begin{array}{l}\text { Resource } \\
\text { theory }\end{array}$ & $\begin{array}{l}\text { Secondary data set of } 457 \\
\text { during } 1996\end{array}$ & $\begin{array}{l}\text { Panel } \\
\text { Analysis }\end{array}$ & $\begin{array}{l}\text { Connecting with other firms will perhaps compensate } \\
\text { the transparency problem in emerging markets. } \\
\text { Hence, interlock mechanisms are positively } \\
\text { associated with firm return. }\end{array}$ \\
\hline $\begin{array}{l}\text { Hoskisso } \\
\mathrm{n} \quad \text { et al. } \\
(2000)\end{array}$ & $\begin{array}{l}\text { Institutional, Transaction } \\
\text { Cost and Resource } \\
\text { Dependence theories }\end{array}$ & $\begin{array}{l}\text { Primary data set of } 75 \\
\text { questionnaires during } 1990 \mathrm{~s} \\
\text { and Secondary data set of } 65 \\
\text { countries during } 1985 \text { and } 1997 \\
\end{array}$ & NA & $\begin{array}{l}\text { As institutions and learning processes in emerging } \\
\text { countries are improving, corporate governance in } \\
\text { emerging markets is expected to follow. }\end{array}$ \\
\hline
\end{tabular}




\section{Research Propositions}

Certain administrative and sociocultural elements have influenced the shaping of corporate governance practices for Saudi Arabia stock market listed companies. For example Saudi Government representative directors (SGRDs) frequently populate the boards of companies with major infrastructure development contracts. Since theoretical and practical frameworks that have examined the relationship between board composition and firm financial performance within the Saudi context are very limited, this paper proposes a series of research propositions (refer Figure 1 below) to make a theoretical contribution.

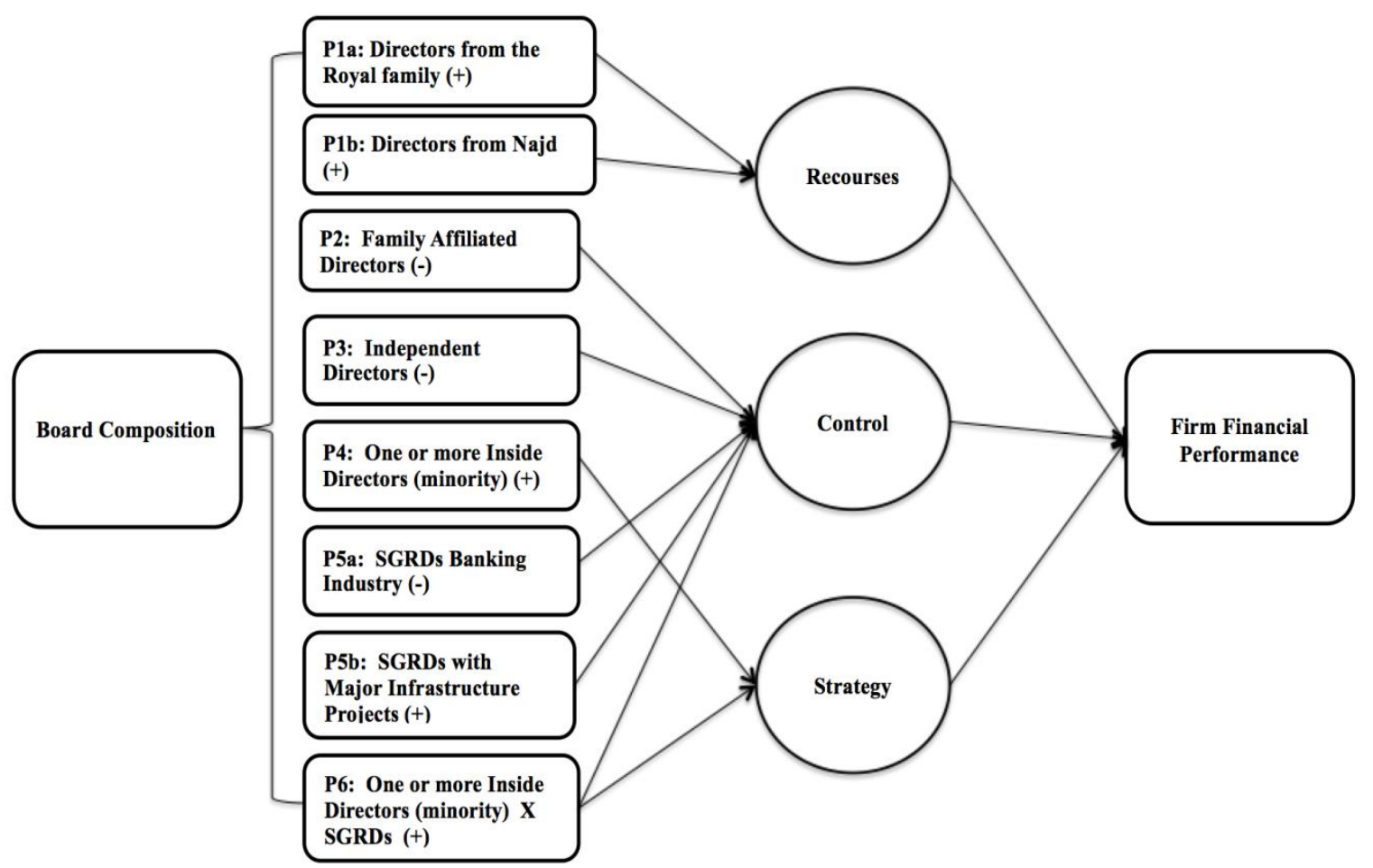

Figure 1. Multi-theoretical model of the effect of board composition on firm financial performance in the emerging saudi arabia market

It has been long documented that the senior members of the Saudi royal family have a major influence initiating and implementing laws and regulations (Bray \& Darlow, 2013). Reed (2009) also noted that members of Saudi royal family have engaged in business activities over the years some of which through participating in multi-billion dollar public projects. As a result of their influence on the political scene and involvement in the local economy, Al-Rasheed (2010) argues that the Saudi royal family has gained a major position in the business community in Saudi Arabia. Applying hegemony theory having outside directors with royal status in the boardroom with social and political influence would provide some influence to a company in relation to government decisions on allocating public projects to the business community for implementation.

Saudi Arabia is also a regional society (Ali, 2008). This social structure has been influenced by people from the region of Najd, who have long been granted the privilege by the Saudi rulers to occupy most of the senior positions in ministries and state firms. Niblock and Malik (2007) suggest that individuals from the region of Najd have come second after the royal family as dominant players on the political and business scenes due to the fact that Najd is the birthplace of the royal family, their deep-rooted influence within the religious establishment, and their long-established involvement in trade. Hence, the presence of outside directors from Najd in a firm can influence the government to grant that firm more favourable treatment.

In keeping with hegemony theory and institutional theory views on the ruling elite and the value of status and influence in Saudi business and society (Davis et al., 2003; Huse et al., 2011) we propose the following:

Pla: Outside directors with royal status are positively associated with firm financial performance in Tadawul listed companies. 


\section{P1b: Outside directors from Najd are positively associated with firm financial performance in Tadawul listed companies.}

Since 60 per cent of the Saudi listed firms are mainly owned and controlled by founding families (Solomon, 2011), most are reluctant to hand over control to non-family members due to concerns in relation to trust. In a study made by Oukil and Khalifah (2012) on Saudi firms located in the Eastern Province, 71 per cent of outside directors were appointed due to family connection with the major stockholders or the chairperson. As the institutional context in emerging countries makes the enforcement of business contracts more challenging and expensive, relying on trusted family members through informal social contracts can help to minimise such risk (Phan, 2001). However, developed economy Anglo-American agency theory argues that a majority of independent outside directors helps to avoid the principal-agent problem emerging in executive decision making. On the other hand family-affiliated outside director objectiveness, input to board deliberation and overall performance can be compromised due to their closeness to founding family majority shareholders (Young et al., 2008). This situation can lead to the development of principal-principal problems with minority stockholders disadvantaged compared with majority stockholders due to a lack of effective representation and influence at board level (Young et al., 2008). On balance this suggests the following:

P2: Appointment of one or more outside directors with family relationships with the firm's major stockholders is negatively associated with firm financial performance in Tadawul listed companies.

Agency theorists have long argued that independent directors provide more objective monitoring of management actions (Dalton et al., 1998). However, we question the independence of these directors in Saudi firms. The reason for this scepticism is that the 'controlling shareholders effectively selects directors in Saudi Arabia' (Ezzine, 2012, p. 30). Since the owners would most likely appoint directors to help them maintain their control, the independence of those directors will be restricted and compromised. Indeed, Davies (2012) has reported that it is difficult to find independent directors across Saudi firms though there has been progress in this area. He indicates that large investors strongly influence the appointment of their social and business affiliates to sit in the boardroom as independent directors. Those directors would officially appear independent but in fact they are rather delegates for the controlling shareholders. This limited independence of these directors could clear the way for the major shareholders to gain total control, resulting in the expropriation of value from minority shareholders to the majority. This situation would negatively affect the quality of board of director thinking and deliberation, limiting objective review of management performance by these directors. This compromised position for independent directors would limit their ability to perform their role (Phan, 2001). Hence:

P3: Independent directors are negatively associated with firm financial performance in Tadawul listed companies.

The debate on the value of inside directors on the boards of Saudi companies is intriguing, reflecting a tension between the local business environment and more internationally accepted Anglo-American developed economy insights on the importance of the value of having one or more inside directors on the board reflecting agency, stewardship and institutional theory. A study made by Ezzine (2012) revealed that less than 10 per cent of board members in Saudi listed firms are insiders; this low ratio indicates controlling shareholders do not see great value in the presence of inside directors on Saudi boards. There is an argument reflecting local business and society that inside directors have very little influence in Saudi companies due to their low representation in boardrooms. As corporate governance in Saudi Arabia is largely driven by cultural norms and customs, and since founding families control the majority of Saudi listed firms (The World Bank, 2009), Sarayrah (2004) argues that Saudi company boards have for a long time perceived managers as merely reporters and 'servants' (p. 68). Following this line of argument inside directors in Tadawul listed companies would add little value to organization performance.

However stewardship theorists suggest that because inside directors are better informed about the "day-to-day" work of the firm and the detail of the strategic plan they can play a more effective role in shaping the strategic direction of the firm compared with other categories of director (Coles et al., 2001; Krause et al., 2014). Non-Saudi inside directors can also bring significant human and social capital through their business education, business training, experience, professional networks and performance track record. Non-Saudi inside directors are valued for their developed economy business experience. Stewardship theory accepts a majority of inside directors on the board as workable due to their common objective with shareholders of the betterment of the firm. Committed inside directors also bring the value of their expert knowledge plus social connection to their employer (Johnson et al., 1996; Boyd et al., 2011). Agency theorists also see a role for a minority of inside directors on the board, arguing that they can add value to board deliberations through their detailed knowledge of 
the strategic plan and their area of executive expertise. Inside directors also have knowledge of their "day-to-day" work and interaction with the chief executive officer (CEO) on which they can keep the board advised (Johnson et al., 1996). This view reflects Anglo-American institutional expectations, which we argue on balance overrides local Saudi business and society views. A quality steward in an inside director role can make a difference, hence:

P4: The presence of one or more inside directors, without a voting majority of inside directors on the board, is positively associated with firm financial performance in Tadawul listed companies.

The value of the presence of Saudi Government representatives on Tadawul company boards and the quality of their contribution to board deliberation is a matter of debate.

The public sector in Saudi Arabia is known to be highly bureaucratic. In 2012, government effectiveness in Saudi Arabia ranked 90th globally (The World Bank, 2013). This high level of bureaucracy can constrain the effectiveness and strategic insight of SGRDs. An empirical study by Al-Hussain (2009) reported that banks with a high level of Saudi government representation recorded the lowest return on assets and stock return ratios. This gives an indication that those directors do not play an effective nor efficient role in monitoring management and improving board deliberations in the banking industry. Hence:

P5a: The presence of SGRDs is associated with below average financial performance in Tadawul listed banking sector companies.

In Saudi Arabia, the government owns more than 25 per cent of the listed firms (CMA, 2012). The Saudi Government has the power to allocate lucrative major projects. The presence of Saudi Government representatives on the board does give legitimacy to the firm tendering for these lucrative contracts. Agency theorists have indicated that government representative directors can also improve control mechanisms due to their presumably high level of independence (Withers et al., 2012). Through its representative directors, the government plays a major role in monitoring management and spending on major projects. According to Al-Majed (2008) 'the state's influence is more perceptible when considering that many corporate chairmen and CEOs of companies in which the state invests have been appointed by the government' (p. 296). In this context SGRDs would have a positive effect on financial performance, hence:

P5b: SGRDs are positively associated with firm financial performance in industries with major infrastructure projects allocated to Tadawul listed companies.

There is the opportunity for a synergy between inside directors - Saudi and non-Saudi - and SGRDs working jointly together. We have seen that Saudi listed firms in industries with major projects can benefit from the presence of SGRDs reflecting resource dependence and institutional theory. Directors with government influence and access is important for companies, not just for their information and potential access, but also for the legitimacy they give (Pfeffer \& Salancik, 1978). According to Hillman et al. (2000, p. 246) 'Regulation is, at its most basic level, a tie with the government - a link to legitimacy'. Complimentary to Saudi Government representatives presence on the board, inside directors are an important source of firm-specific knowledge applying stewardship theory. We have seen that inside director presence in the boardroom can enhance the overall effectiveness of the board of directors (Nicholson \& Kiel, 2007). Agency theorists see inside directors in the voting and numerical minority on the board as being a valuable firm resource (Boyd et al., 2011). By aligning the assumption of resource dependence and institutional theory in relation to the role of government representative directors (Hillman et al., 2000) with stewardship theory views on the value of native Saudi and non-Saudi inside directors (Krause et al., 2014) there is the opportunity for a joint multiplicative effect. Hence:

P6: The presence of one or more inside directors in the minority on the board working jointly with SGRDs in companies in industries with major infrastructure projects predict firm financial performance in Tadawul listed companies in a positive relationship.

\section{Discussion and Conclusion}

This paper has been inspired by the knowledge that applying advanced stock market corporate governance theory in an emerging markets context without considering the unique business and social aspects of those countries can limit the quality of the theoretical contribution (Wright et al., 2005). Sensitivity to context is particularly crucial for theory development in this corporate governance context in an emerging market area (Fan et al., 2011). According to the contextualist approach (Gergen, 2001) pattern of meaning is rooted in the context, with a need to appreciate the importance of where and when the practice of corporate governance happens. Whetten (1989) has explained that 'observations are embedded and must be understood within a context' (p. 492). So the context of a country is an important consideration when developing theory on corporate governance in a particular emerging market country. What may work in a corporate governance context in an Anglo context 
such as Australia or the United Kingdom may not necessarily apply in a Middle East country such as Saudi Arabia with different business, economic, social and legal conditions. So the propositions developed here are informed by agency, hegemony, institutional, resource dependence and stewardship theory specific to the situation (e.g. the presence of the royal family on a board) for the unique Saudi business, economic, social and legal context.

On balance considering the arguments presented here agency theory has a limited role in Saudi business practice, limited to the use of government representatives on Tadawul listed company boards. The issue of trust has more impact on work practices in Eastern societies than in Western Anglo-American countries (Floyd, 1999). To limit this risk of a breach of trust, the majority of the Saudi listed firms are substantially owned and controlled by the founding families with independent and outside directors often owing their position to some family affiliation. This set of circumstances in Saudi business and society limits the value of agency theory and has relevance to other emerging markets where legal statutes and legal precedent established in law courts is not mature and doing business with family affiliates encourages trust (Phan, 2001).

Hegemony theory (Davis et al., 2003) is prominent and influential in the Saudi business context given the practical role of the ruling elites in enhancing firm financial performance. Considering that Saudi Arabia is ruled by the royal family in partnership with the rest of the local citizens but largely with individual from the region of Najd, we have seen that Saudi firms with outside directors from the royal family or Najd benefit from the privileged political and social status of those directors, and are able to lobby for access to major projects allocated by the government. So theoretically by extension countries with a royal family and/or a privileged section or region of society active in business and economic life, holding board positions on companies will be able to use their high social esteem to lobby for access to major government or perhaps private sector funded projects. This will result in favourable financial performance when major government funded projects are allocated to these socially well-connected companies.

Institutional theory has an important place in Saudi corporate governance practice. The Royal family are a notable, esteemed and influential institution in Saudi with much influence in all walks of life. In practice the Saudi Government is an important institution and its representatives have an important role monitoring government funded investments and projects. Their influence on the Saudi economic, business and social scene cannot be underestimated. Government representative directors can provide information, potential access to key public servants and politicians, and lend legitimacy to firms (Hillman et al., 2000). The Tadawul also has a new and important institutional role in the Saudi business and economic scene. The evolution of the Saudi legal system and legal precedent in Saudi courts of law, regulation of the stock exchange and oversight of director's duties will be interesting to watch in future years. In theory these observations are applicable in other emerging market contexts where there is a monarchy, major government funded projects and/or investment in listed companies, an emerging stock market supported by an emerging legal system of statutes and courts (Whetten, 2009).

Resource dependence theory has been evidenced to apply in relation to the role of government representatives on Saudi boards who can provide a useful source of information and advice. The resource dependence role of outside directors and independent directors remains in practice, despite the inclination for founding families to make family affiliated appointments. This family affiliation does not preclude outside and independent directors assisting the organization in accessing financial, legal or consulting resources. In an emerging market context outside Saudi this resource dependence role could reasonably be expected to apply (Xu \& Meyer, 2013).

Stewardship theory also has a positive place in Saudi corporate governance practice. On balance in theory and practice we argue that both native Saudi and non-Saudi inside directors have an important positive role as effective stewards of company resources whose interests align with shareholders with majority ownership. Well trained and experienced inside directors are trustworthy, well informed on company strategy, good stewards of resources and gain much personal satisfaction from their contribution and commitment to the firm (Donaldson \& Davis, 1991; Krause et al., 2014). We argue that considering the evidence stewardship theory applies equally to inside directors in advanced stock market and the emerging stock market context.

\subsection{Limitations}

A potential limitation of this paper is that the insights presented have been informed by corporate governance literature applied to the Saudi context, leaving some of the propositions presented here helpful in some national settings in emerging markets with similar characteristics but not helpful in others. For example the proposition in relation to outside directors from a particular region with social, economic and political status is also not applicable for countries where regionalism does not have an influence on the political or economic scenes. 
However, regional status can be substituted by ethnic or religious status as applicable in an emerging market context. Hence, the propositions presented here need to be carefully considered in combination with the context of other emerging countries when seeking to adapt the theory presented in this paper to theory development or practice for other emerging markets.

\subsection{Future Research}

Withers et al. (2012) and Johnson et al. (2013) have observed that a multi-theoretic approach will lead to a more comprehensive understanding of the relationship between board composition and firm financial performance. The value of inside directors to stock exchange listed companies in particular is under researched in advanced and emerging markets and requires more empirical insight. Most theory development in corporate governance has been conducted in the advanced economies context, leaving little or no consideration for emerging markets unique social, political, and economic contexts (Phan, 2001; Xu \& Meyer, 2013). The theory development presented here takes a step towards conducting an empirical investigation based on multiple theoretical approaches in an emerging market drawing on agency, hegemony, resource dependence, and stewardship theories. This has the potential to lead to a useful empirical contribution to the literature with future research, examining the research propositions presented here perhaps by developing an archival quantitative data set, qualitative interviews and/or a case study. These research propositions can also be adapted to other emerging markets (Whetten, 2009; Kearney 2012). This is a substantial future research agenda.

\subsection{Conclusion}

Saudi Arabia is a fascinating country with its unique business, economic, legal and social context impacting corporate governance practice on its emerging stock market the Tadawul. This paper has set out to better understand the relationship between board composition and firm financial performance in that country context and then extend that insight to how it may apply in other emerging market contexts with their own unique business, economic, legal, social and possibly religious conditions.

\section{References}

Al-Hussain, A. (2009). Corporate Governance Structure Efficiency and Bank Performance. University of Phoenix Press, Phoenix.

Ali, A. (2008). Business and Management Environment: Challenges and Opportunities For Multinational Corporations. London: Routledge.

Allen, F. (2005). Corporate Governance in Emerging Economies. Oxford Review of Economic Policy, 21, 164-177. http://dx.doi.org/10.1093/oxrep/gri010

Al-Majed, F. (2008). A Conceptual Framework for Reforming the Corporate Governance of Publicly Held Companies: a Comparative and Analytical Study from a Legal Perspective. SABIC Publications, Riyadh.

Al-Matari, Y., Al-Swidi, A., \& Fadzil, F. (2012). Corporate Governance and Performance of Saudi Arabia Listed $\begin{array}{lllll}\text { Companies. British Journal of Arts \& Social Sciences, } & \text { 9, } & \text { 1-30. }\end{array}$ http://dx.doi.org/BJASS_9_1/BJASS_09_01_01

Al-Rasheed, M. (2010). A History of Saudi Arabia. Cambridge: Cambridge University Press.

Al-Twaijry, A. (2007). Saudi Stock Market Historical View and Crisis Effect: Graphical and. Statistical Analysis. Journal of Human Science, 5, 1-31. http://dx.doi.org/10.1111/1467-8683.00293

Bazerman, M., \& Schoorman, F. (1983). A Limited Rationality Model of Interlocking Directorates. Academy of Management Review, 8, 206-217. http://www.jstor.org/stable/257747

Boyd, B., Haynes, K., \& Zona, F. (2011). Dimensions of CEO-Board Relations. Journal of Management Studies, 48, 1892-1923. http://dx.doi.org/10.1111/j.1467-6486.2010.00943.x

Bray, B., \& Darlow, M. (2013). Ibn Saud: The Desert Warrior Who Created the Kingdom of Saudi Arabia. New York: Skyhorse Publishing.

Burris, V. (2005). Interlocking Directorates and Political Cohesion Among Corporate Elites. American Journal of Sociology, 111, 249-283. http://dx.doi.org/10.1086/428817

Claessens, S., \& Yurtoglu, B. (2013). Corporate Governance in Emerging Markets: A Survey. Emerging Markets Review, 15, 1-33. http://dx.doi.org/10.1016/j.ememar.2012.03.002

CMA. (2012). Аnпual Report - 2012. Riyadh: Capital Market Authority Publications.

Coles, J., McWilliams, V., \& Sen, N. (2001). An Examination of The Relationship of Governance Mechanisms to 
Performance. Journal of Management, 27, 23-50. http://dx.doi.org/10.1177/014920630102700102

Dalton, D., Daily, C., Ellstrand, A., \& Johnson, J. (1998). Meta-Analytic Reviews of Board Composition, Leadership Structure, and Financial Performance. Strategic Management Journal, 19, 269-290. http://dx.doi.org/10.1002/(SICI)1097-0266(199803)19:3<269::AID-SMJ950>3.0.CO;2-K

Davies, A. (2012). The Globalisation of Corporate Governance: The Challenge of Clashing Cultures. Gower Publishing Ltd, Surrey.

Davis, G., Yoo, M., \& Baker, W. (2003). The Small World of the American Corporate Elite, 1982-2001. Strategic Organization, 31, 301-326. http://dx.doi.org/10.1177/14761270030013002

Donaldson, L., \& Davis, J. (1991). Stewardship Theory or Agency Theory: CEO Governance and Shareholder Returns. Australian Journal of Management, 16, 49-64. http://dx.doi.org/10.1177/031289629101600103

Ezzine, H. (2012). A Cross Saudi Firm Analysis $f$ the Impact of Corporate Governance on the Stock Price Performance During the Recent Financial Crisis. SABIC Publications, Riyadh.

Fan, J. P., Wei, K. C., \& Xu, X. (2011). Corporate Finance and Governance in Emerging Markets: A Selective Review and An Agenda for Future Research. Journal of Corporate Finance, 17, 207-214. http://dx.doi.org/10.1016/j.jcorpfin.2010.12.001

Floyd, D. (1999). Eastern and Western Management Practices: Myth or Reality? Management Decision, 37, 628-632. http://dx.doi.org/10.1108/00251749910291596

Gergen, K. (2001). Social Construction in Context. London: Sage Publications.

Hillman, A., Cannella, A., \& Paetzold, R. (2000). The Resource Dependence Role of Corporate Directors: Strategic Adaptation of Board Composition in Response to Environmental Change. Journal of Management Studies, 37, 235-256. http://dx.doi.org/10.1111/1467-6486.00179

Hoskisson, R., Eden, L., Lau, C., \& Wright, M. (2000). Strategy in Emerging Economies. Academy of Management Journal, 43, 249-267. http://dx.doi.org/10.2307/1556394

Huse, M., Hoskisson, R., Zattoni, A., \& Vigano, R. (2011). New Perspectives on Board Research: Changing the Research Agenda. Journal of Management \& Governance, 15, 5-28. http://dx.doi.org/10.1007/s10997-009-9122-9

Jensen, M., \& Meckling, W. (1976). Theory of the Firm: Managerial Behavior, Agency Costs and Ownership Structure. Journal of Financial Economics, 3, 305-360. http://dx.doi.org/10.1016/0304-405X(76)90026-X

Johnson, J., Ellstrand, A., \& Daily, C. (1996). Boards of Directors: A Review and Research Agenda. Journal of Management, 22, 409-438. http://dx.doi.org/10.1177/014920639602200303

Johnson, S., Schnatterly, K., \& Hill, A. (2013). Board Composition Beyond Independence Social Capital, Human $\begin{array}{llll}\text { Capital, and Demographics. Journal of Management, 39, 232- } & \text { 262. }\end{array}$ http://dx.doi.org/10.1177/0149206312463938

Karolyi, G. A. (2012). Corporate Governance, Agency Problems and International Cross-Listings: A Defense of the Bonding Hypothesis. Emerging Markets Review, 13, 516-547. http://dx.doi.org/10.1016/j.ememar.2012.08.001

Kearney, C. (2012). Emerging Markets Research: Trends, Issues and Future Directions. Emerging Markets Review, 13, 159-183.

Khanna, T., \& Thomas, C. (2009). Synchronicity and Firm Interlocks in An Emerging Market. Journal of Financial Economics, 92, 182-204. http://dx.doi.org/10.1016/j.ememar.2012.01.003

Klapper, L., \& Love, I. (2004). Corporate Governance, Investor Protection, and Performance in Emerging Markets. Journal of Corporate Finance, 10, 703-728. http://dx.doi.org/10.1016/j.jfineco.2008.03.005

Krause, R., Semadeni, M., \& Cannella, A. (2014). CEO Duality - A Review and Research Agenda. Journal of Management, 40, 256-286. http://dx.doi.org/10.1177/0149206313503013

Mallin, C. (2013). Corporate Governance. Oxford: Oxford University Press.

Marquis, C., \& Raynard, M. (2015). Institutional Strategies in Emerging Markets. The Academy of Management Annals, 9, 291-335. http://dx.doi.org/10.1080/19416520.2015.1014661

Millar, C., Eldomiaty, T., Choi, C., \& Hilton, B. (2005). Corporate Governance and Institutional Transparency in Emerging Markets. Journal of Business Ethics, 59, 163-174. http://dx.doi.org/10.1007/s10551-005-3412-1 
Mueller, D. (2006). The Anglo Saxon Approach to Corporate Governance and its Applicability to Emerging Markets. Corporate Governance: An International Review, 14, 207-219.

Niblock, T., \& Malik, M. (2007). The Political Economy of Saudi Arabia. New York: Routledge.

Nicholson, G., \& Kiel, G. (2007). Can Directors Impact Performance? A Case-Based Test of Three Theories of Corporate Governance. Corporate Governance: An International Review, 15, 585-608. http://dx.doi.org/10.1111/j.1467-8683.2007.00590.x

Oukil, M., \& Al-Khalifah, H. (2012). Managerial Weaknesses and Features of Family Businesses in the Eastern Region of Saudi Arabia. International Conference on Economics, Business and Marketing Management, 29, 49-54. http://dx.doi.org/74274180

Peng, M. (2004). Outside Directors and Firm Performance During Institutional Transitions. Strategic Management Journal, 25, 453-471. http://dx.doi.org/10.1.1.126.2347

Perrow, C. (1986). Complex Organizations: A Critical Essay. New York: McGraw-Hill.

Pfeffer, J. (1972). Size and Composition of Corporate Boards of Directors. Administrative Science Quarterly, 17, 218-229. http://dx.doi.org/10.2307/2393956

Pfeffer, J., \& Salancik, G. (1978). The External Control of Organizations: A Resource Dependence Perspective. New York: Harper and Row.

Phan, P. (2001). Corporate Governance in The Newly Emerging Economies. Asia Pacific Journal of Management, 18, 131-136. http://dx.doi.org/10.1023/A:1010630320396

Reed, J. (2009). The Saudi Royal Family. New York: Infobase Publishing.

Sarayrah, Y. (2004). Servant Leadership in the Bedouin-Arab Culture. Global Virtue Ethics Review, 5, 58-79. http://dx.doi.org/1P3-1011232771

Solomon, J. (2011). Corporate Governance and Accountability. Sussex: John Wiley \& Sons.

The World Bank. (2009). Corporate Governance Country Assessment - Kingdom of Saudi Arabia. Retrieved from http://www.worldbank.org/ifa/rosc_cg.html

The World Bank. (2013). The World Bank Indicators for Economy and Growth. Retrieved from http://data.worldbank.org/indicator/BX.KLT.DINV.CD.WD

Useem, M. (1984). The Inner Circle. New York: Oxford University Press.

Whetten, D. (1989). What Constitutes a Theoretical Contribution? Academy of Management Review, 14, 490-495. http://dx.doi.org/10.5465/AMR.1989.4308371

Whetten, D. (2009). An Examination of the Interface Between Context and Theory Applied to the Study of Chinese Organizations. Management and Organization Review, 5, 29-55. http://dx.doi.org/10.1111/j.1740-8784.2008.00132.x

Withers, M., Hillman, A., \& Cannella, A. (2012). A Multidisciplinary Review of the Director Selection Literature. Journal of Management, 38, 243-277. http://dx.doi.org/10.1177/0149206311428671

Wright, M., Filatotchev, I., Hoskisson, R., \& Peng, M. (2005). Strategy Research in Emerging Economies: Challenging the Conventional Wisdom. Journal of Management Studies, 42, 1-33. http://dx.doi.org/10.1111/j.1467-6486.2005.00487.x

Xu, D., \& Meyer, K. E. (2013). Linking Theory and Context: 'Strategy Research in Emerging Economies' after Wright et al. 2005. Journal of Management Studies, 50, 1322-1346. http://dx.doi.org/10.1111/j.1467-6486.2012.01051.x

Young, M., Peng, M., Ahlstrom, D., Bruton, G., \& Jiang, Y. (2008). Corporate Governance in Emerging Economies: A Review of the Principal-Principal Perspective. Journal of Management Studies, 45, 196-220. http://dx.doi.org/10.1111/j.1467-6486.2007.00752.x

Zahra, S., \& Pearce, J. (1989). Boards of Directors and Corporate Financial Performance: A Review and Integrative Model. Journal of Management, 15, 291-334. http://dx.doi.org/10.1177/014920638901500208

Note

Note 1. For the purpose of this study of Tadawul, an independent director is defined as an individual who is not a 
controlling shareholder, has no material or pecuniary relationship with the firm or related persons except sitting fees, not a first degree relative of a senior executive or board member and not an employee of an affiliate company (The World Bank, 2009). An outside director is defined as an individual who has had no executive position for two years and otherwise does not meet the definition of an independent director. An inside director is a top manager who also serves on the board of directors.

\section{Copyrights}

Copyright for this article is retained by the author(s), with first publication rights granted to the journal.

This is an open-access article distributed under the terms and conditions of the Creative Commons Attribution license (http://creativecommons.org/licenses/by/3.0/). 